\title{
Cytoreduction Treatment
}

National Cancer Institute

\section{Source}

National Cancer Institute. Cytoreduction Treatment. NCI Thesaurus. Code C155678.

Any therapy designed to reduce the number of cells of a particular type or in a particular location. 